\title{
POJAM UBROJIVOSTI U KAZNENOPRAVNOJ TEORIJI, ZAKONODAVSTVU I PRAKSI ${ }^{1}$
}

Doc. dr. sc. Igor Martinović*
UDK: 343.225

Ur.: 11. rujna 2017.

Pr.: 6. studenoga 2017.

Pregledni znanstveni rad

\section{Sažetak}

Kazneni zakon ubrojivost određuje kao jedan od sastojaka krivnje. Taj pojam zakon ne definira, ali zato definira neubrojivost (čl. 24.), samoskrivljenu ubrojivost (čl. 25.) i bitno smanjenu ubrojivost (čl. 26.). U radu se prvo obrađuje pojam neubrojivosti, osobito njegova „biopsihološka" $i$,normativna“ sastavnica. Raspravlja se i o odnosu suca i psihijatra pri utvrđivanju ubrojivosti. Nakon toga se analiziraju pojmovi bitno smanjene ubrojivosti i samoskrivljene neubrojivosti, pri čemu se razmatraju ,model iznimke" $i$,model bića djela“. U završnom dijelu rada raspravlja se o mogućnosti izricanja sigurnosnih mjera neubrojivim osobama de lege lata i de lege ferenda. U cijelom se radu kritički analiziraju sudske odluke vezane uz navedene zakonske i teorijske institute.

Ključne riječi: ubrojivost, neubrojivost, smanjena ubrojivost, samoskrivljena neubrojivost, kazneno pravo.

\section{1. $U V O D$}

Kazneni zakon (u daljnjem tekstu: KZ) u čl. 23. propisuje da je za kazneno djelo kriv počinitelj koji je u vrijeme počinjenja kaznenog djela bio ubrojiv, koji je postupao s namjerom ili iz nehaja, koji je bio svjestan ili je bio dužan i mogao biti svjestan da je njegovo djelo zabranjeno, a ne postoji nijedan ispričavajući razlog. Među navedenim sastojcima krivnje, prominentno mjesto zauzima pojam ubrojivosti. Njega zakon, doduše, ne definira, ali zato definira neubrojivost (čl. 24. st. 2. KZ) kao njegovu negaciju i propisuje da neubrojiva osoba nije kriva, zbog čega joj se ne može izreći kazna (čl. 24. st. 1. KZ). Osim ubrojivosti i neubrojivosti, KZ uređuje i institut samoskrivljene neubrojivosti (čl. 25.) te bitno smanjene ubrojivosti (čl. 26.). U teoriji i praksi pojam ubrojivosti i njegovi derivati izazivaju različite dvojbe, o kojima će više riječi biti u nastavku rada.

* Dr. sc. Igor Martinović, docent Pravnog fakulteta Sveučilišta u Rijeci; imartinovic@pravri.hr

1 Ovaj rad je sufinancirala Hrvatska zaklada za znanost projektom IP-11-2013-2287 „Legal Status and Real Position of People with Mental Difficulties - Interdisciplinary Approach and European Perspectives" i Sveučilište u Rijeci potporama znanstvenim istraživanjima 13.08.1.3.02 "Interdisciplinarni pristup u istraživanju statusa osoba s duševnim smetnjama kroz prizmu konvencijskog prava". 


\section{POJAM NEUBROJIVOSTI I NJEGOVA „BIOPSIHOLOŠKA“ SASTAVNICA}

Sukladno čl. 24. st. 2. KZ, neubrojiva je osoba koja u vrijeme ostvarenja protupravnog djela nije mogla shvatiti značenje svojeg postupanja ili nije mogla vladati svojom voljom zbog duševne bolesti, privremene duševne poremećenosti, nedovoljnog duševnog razvitka ili neke druge teže duševne smetnje.

Zakonski i teorijski kontinuitet instituta neubrojivosti (neuračunljivosti) postoji još od kraja dvadesetih godina dvadesetog stoljeća, kada je inauguracijom toga pojma napušten zastarjeli koncept ,zle nakane“ iz austrijskog (i hrvatskog) Kaznenog zakona o zločinstvima, prijestupima i prekršajima. Definicija iz Krivičnog zakonika Kraljevine Jugoslavije propisivala je, naime, da „neće biti odgovoran, tko u vrijeme učinjenja djela nije mogao shvatiti prirodu i značaj svog djela ili prema tome shvaćanju raditi uslijed duševnog rastrojstva ili pomućenja svijesti ili umne nerazvijenosti ili slaboumnosti“ (čl. 22.). Slično tome, Krivični zakonik iz 1951. propisivao je da „nije krivično odgovorna osoba koja je učinila krivično djelo u stanju trajne ili privremene duševne bolesti, privremene duševne poremećenosti ili zaostalog društvenog razvoja, ukoliko uslijed ovih stanja nije mogla shvatiti značenje svog djela ili nije mogla upravljati svojim postupcima“ (čl. 6. st. 1.). Jedina iole važna zakonska izmjena sastoji se u dodavanju „druge teže duševne smetnje“ kao četvrte osnove neubrojivosti u KZ iz 1997. ${ }^{2}$

Iz aktualnog KZ-a, a i iz nekadašnjih zakona, može se zaključiti da pojam neubrojivosti sačinjavaju dvije sastavnice: (1) duševna bolest, privremena duševna poremećenost, nedovoljni duševni razvitak ili neka druga teža duševna smetnja te (2) nemogućnost shvaćanja značenja svojeg postupanja ili nemogućnost vladanja svojom voljom. Domaći autori te dvije sastavnice nazivaju različitim imenima. Prva sastavnica obično se naziva biološkom ${ }^{3}$ ili biopsihološkom, ${ }^{4}$ dok se druga naziva psihološkom ${ }^{5}$ ili normativnom. ${ }^{6}$ Metoda utvrđivanja (ne)ubrojivosti koja kombinira navedene dvije sastavnice u literaturi se naziva biološko-psihološkom ${ }^{7}$ odnosno biopsihološko-normativnom. ${ }^{8}$

Upuštati se u opširnu raspravu o prednostima ovog ili onog naziva nije potrebno, no i na tu je temu nužno iznijeti nekoliko primjedaba jer se iza terminoloških rasprava

2 Tako i Škorić, M. i Srdoč, E., Pravni položaj neubrojivih počinitelja protupravnih djela u Republici Hrvatskoj, Zbornik radova Pravnog fakulteta u Splitu, vol. 52., br. 4., 2015., str. 935.

3 Tako Frank, S., Teorija kaznenog prava, Zagreb, Školska knjiga, 1955., str. 141; Srzentić, N., Stajić, A., Lazarević, Lj., Krivično pravo SFRJ - opšti deo, Beograd, Savremena administracija, 1978., str. 214.

4 Bačić, F., Kazneno pravo - opći dio, Zagreb, Informator, 1998., str. 218; Grozdanić, V., Škorić, M., Martinović, I., Kazneno pravo - opći dio, Rijeka, Pravni fakultet Sveučilišta u Rijeci, 2013., str. 137.; Novoselec, P., Opći dio kaznenog prava, Osijek, Pravni fakultet Osijek, 2016., str. 210.

5 Frank, S., op. cit., str. 141; Srzentić, N., Stajić, A., Lazarević, Lj., op. cit., str. 214.

6 Bačić, F., op. cit., str. 218; Novoselec, P., op. cit., str. 213.

7 Frank, S., op. cit., str. 141; Srzentić, N., Stajić, A., Lazarević, Lj., op. cit., str. 213; Grozdanić, V., Škorić, M., Martinović, I., op. cit., str. 136; Novoselec, P., op. cit., str. 209.

8 Bačić, F., op. cit., str. 218. 
katkada kriju konceptualne razlike u shvaćanju neubrojivosti i uloge psihijatra i suca u njezinu utvrđivanju. Te su primjedbe sljedeće: nazivanjem težih duševnih smetnji „biološkom“ sastavnicom neubrojivosti previđa se da sve one nisu nužno biološkog, organskog podrijetla; nadalje, kada se mogućnost shvaćanja značenja svojeg postupanja i vladanja svojom voljom označava kao „psihološka“ sastavnica neubrojivosti, propušta se primijetiti da je u toj domeni ključna normativna ocjena. ${ }^{9}$ Međutim, ni pojam „,biopsihološke“ umjesto „psihološke“ sastavnice ne zadovoljava u potpunosti jer je već na toj razini potrebna normativna ocjena, osobito pri procjeni je li određena smetnja „teža“ duševna smetnja u smislu KZ-a. Ni korištenje sintagme „normativna“ umjesto „psihološke“ sastavnice također nije najbolje rješenje jer procjena ljudskih intelektualnih i voljnih mogućnosti ne može biti u domeni „čistog“, empirijski nedostupnog vrednovanja. Zbog navedenoga bi imenovanje pojedinih sastavnica neubrojivosti valjalo izbjegavati ili ga eventualno koristiti u didaktičke svrhe. Metodu utvrđivanja neubrojivosti najpreciznije bi, pak, bilo nazivati psihološkonormativnom metodom ili, jednostavnije, mješovitom metodom.

Budući da ocjena o postojanju teže duševne smetnje nije lišena normativne ocjene, i to ne neke apstraktne, općevažeće vrijednosne ocjene, nego ocjene koja se donosi u specifičnom kaznenopravnom kontekstu i koja se odnosi na konkretno djelo, postavlja se pitanje je li uopće potrebno zakonsko nabrajanje „biopsiholoških“ osnova neubrojivosti ili bi se taj dio zakonske odredbe mogao izostaviti s obzirom na to da je i on vrijednosno impregniran u jednakoj ili gotovo jednakoj mjeri kao „psihološka“ („,normativna“) sastavnica. Kada bi se izostavila „biopsihološka“ komponenta, odredba o neubrojivosti glasila bi: „Neubrojiva je osoba koja u vrijeme ostvarenja protupravnog djela nije mogla shvatiti značenje svojeg postupanja ili nije mogla vladati svojom voljom“. Iz perspektive hrvatske kaznenopravne tradicije, izmjena bi se na prvi pogled mogla učiniti radikalnom, no na komparativnoj razini takvo rješenje ne bi bilo neobično. Vrijedi spomenuti da švicarski Kazneni zakonik u čl. 19. st. 1., bez nabrajanja „biopsiholoških“ osnova, neubrojivog počinitelja definira kao osobu koja „u trenutku djela nije bila sposobna uvidjeti nepravo svojeg djela ili se vladati u skladu s tom spoznajom". I u Njemačkoj su postojale inicijative da se definicija na sličan način skrati, ${ }^{10}$ ali su takvi prijedlozi odbijeni jer je postojao strah da bi sud bio lišen temelja na koji bi nadovezivao svoju odluku o neubrojivosti, što bi posljedično dovelo do prevelike arbitrarnosti i pravne nesigurnosti. Premda takva bojazan možda ima smisla u Njemačkoj u kojoj psihijatrijsko vještačenje u slučajevima sumnje na neubrojivost nije obvezno, ${ }^{11}$ pa je u nedostatku vještačkoga nalaza i mišljenja sud taj koji samostalno postavlja „pseudo-dijagnozu“ teže duševne smetnje, koja služi kao potkrepa odluke o neubrojivosti ili smanjenoj ubrojivosti, kod nas je psihijatrijsko vještačenje u slučaju sumnje na neubrojivost obvezno temeljem čl. 325. st. 1. Zakona o kaznenom postupku, pa ulogu izvanpravnog legitimiranja odluke o ubrojivosti ne igra sučeva „pseudo-dijagnoza“, nego nalaz i mišljenje vještaka psihijatra.

9 Novoselec, P., op. cit., str. 210; Roxin, C., Strafrecht - Allgemeiner Teil, sv. 1, München, Beck, 2006., str. 886.

10 Protokolle des Sonderausschusses des Deutschen Bundestages für die Strafrechtsreform, Wahlperiod V, str. 478.

11 V. npr. Beulke, W., Strafprozessrecht, Heidelberg, Müller, 2010., str. 128. 
Imajući u vidu da se u podlozi odluke o ubrojivosti ionako mora nalaziti psihijatrijska dijagnoza, koja nije i ne može biti istovjetna nazivima „biopsiholoških“ osnova koje navodi zakon, utvrđivanje „,biopsihološke“ osnove pokazuje se suvišnom međufazom koja nije bitna za utvrđivanje korelacije između duševne smetnje (uzroka) te intelektualnih i voljnih mogućnosti počinitelja (posljedica), tim više što je pojam „teže duševne smetnje“ toliko širok da se pod njega može podvesti svaka duševna smetnja koja je posljedično dovela do isključenja mogućnosti shvaćanja ili vladanja. To potvrđuje i sudska praksa, npr. kada se navodi da je ,provedenim vještačenjem (...) bilo utvrđeno da kod optuženika u vrijeme počinjenja djela nije postojala duševna bolest, privremena duševna poremećenost niti nedovoljni duševni razvitak (...). Vještak je utvrdio psihičke smetnje karaktera organskog psihosindroma, što dovodi do poremećaja ličnosti i poremećaja ponašanja (...). Navedene psihičke smetnje uključuju slabljenje mišljenja, shvaćanja, razumijevanja - misaone obrade (u manjoj mjeri) te voljno emocionalno mijenjanje ličnosti (...) u jačem opsegu ispoljenosti $s$ popratnim teškoćama u ponašanju, u smislu poštivanja uobičajenih društvenih normi i prilagodbe (...). Ponašanje optuženika karakteriziraju opisane psihičke slabosti koje zadovoljavaju, prema vještaku, kriterije ocjene druge teže duševne smetnje trajnog karaktera. Tempore criminis optuženikove sposobnosti shvaćanja vlastitih postupaka bile su očuvane, a sposobnost vladanja vlastitom voljom smanjena" (VSRH, I Kž31/16). Iz navedenog citata jasno se vidi da je u fokusu vještačkog nalaza i mišljenja utvrđivanje dijagnoze i opisivanje njezinih simptoma te mišljenje vještaka o tome kakav je utjecaj smetnje na intelektualne i voljne kapacitete, a ne pitanje može li se određena smetnja kategorizirati pod ovu ili onu „biopsihološku“ osnovu. I u drugim slučajevima (v. npr. VSRH, I Kž-520/15) sudovi se ponajprije usredotočuju na vezu između duševne smetnje (uzroka) i mogućnosti počinitelja da shvati značenje svojeg postupanja i vlada svojom voljom (posljedice). Ocjena o tome je li određena smetnja duševna bolest, privremena duševna poremećenost, nedovoljan duševni razvitak ili neka druga teža duševna smetnja sporedno je pitanje.

S obzirom na navedeno, zakonsko je propisivanje „biopsiholoških“ osnova suvišno. Štetnih posljedica, doduše, neće biti ni ako ih zakonodavac, iz tradicijskih razloga ili pukog opreza, zadrži u zakonu, no ako mu je stalo do pregnantnosti i ekonomičnosti izričaja, treba ih brisati. Umjesto upuštanja u nepotrebnu diskusiju o „biopsihološkim“ osnovama, u nastavku će biti riječi o ,psihološkoj“ (,,normativnoj“) sastavnici neubrojivosti. 


\section{MOGUĆNOST SHVAĆANJA ZNAČENJA SVOJEG POSTUPANJA I MOGUĆNOST VLADANJA SVOJOM VOLJOM}

\subsection{Odnos psihijatra i suca pri utvrđivanju „psihološke“ (,normativ- ne") sastavnice neubrojivosti}

Samo postojanje duševne bolesti, privremene duševne poremećenosti, nedovoljnog duševnog razvitka ili neke druge teže duševne smetnje nije dovoljno za donošenje zaključka o neubrojivosti počinitelja. Ključno je, naprotiv, pitanje je li počinitelj u trenutku počinjenja djela bio u mogućnosti shvatiti značenje svojeg postupanja odnosno vladati svojom voljom. Prema starijim shvaćanjima, utvrđivanje „biopsihološke“ osnove u domeni je vještaka-psihijatra, dok je sud o utjecaju tih osnova na intelektualne i voljne mogućnosti počinitelja u rukama suca. Ratio je takve podjele uloga u ideji da su ,biopsihološke“ osnove nešto egzaktno, empirijski dostupno stručnoj osobi, dok je ,,psihološka“ (,normativna“) sastavnica empirijski nedostupna ${ }^{12}$ i stoga u domeni sučeve normativne ocjene. Međutim, takva je podjela uloga iluzorna ima li se u vidu da su i ,biopsihološke“ osnove impregnirane vrednovanjem (osobito pojam ,teže“ duševne smetnje), ali i zato što je ideja da psihijatar nema što za reći o intelektualnim i voljnim kapacitetima počinitelja pogrešna. Ta ideja, čini se, refleks je filozofskih koncepcija koje inzistiraju na oštrom razgraničenju „bitka“, u kojem vrijede mehanicističke uzročno-posljedične veze i koji je empirijski spoznatljiv, i „trebanja“, koje je onkraj pozitivističke znanosti i u kojem se vrši nekakvo mistično „,čisto“ vrednovanje. Suprotno tome, primarna korist nalaza i mišljenja vještaka upravo je u tome da rasvijetli pitanje jesu li počiniteljeve sposobnosti shvaćanja i vladanja bile očuvane; drugim riječima, je li njegovo duševno stanje bilo takvo da se mogao pokoriti pravnoj normi, tj. je li ga se u trenutku počinjenja moglo ,ubrojiti“ među adresate norme. To, dakako, ne znači da nalaz i mišljenje vještaka mogu zamijeniti odluku suca, nego da su za odluku važni i mišljenje vještaka i mišljenje suca.

Daljnje je pitanje što učiniti kada sud ne poklanja vjeru nalazu ili mišljenju vještaka o tome postoji li određena duševna smetnja te kakav je njezin utjecaj na intelektualne i voljne kapacitete počinitelja. Ako takvo neslaganje počiva na ocjeni suda da je nalaz vještaka nejasan, nepotpun ili u proturječnosti sam sa sobom ili s izviđenim okolnostima, a ti se nedostaci ne mogu otkloniti ponovnim ispitivanjem vještaka, obnovit će se vještačenje s istim ili drugim vještakom (čl. 317. Zakona o kaznenom postupku). Analogno tome, ako u mišljenju vještaka ima proturječnosti ili nedostataka ili se pojave osnove sumnje u točnost danog mišljenja, a ti se nedostaci ili sumnja ne mogu otkloniti ponovnim ispitivanjem vještaka, zatražit će se mišljenje drugog vještaka (čl. 318. Zakona o kaznenom postupku). Moguće je, međutim, da ni obnovljena vještačenja ne urode nalazom i mišljenjem kojima sud poklanja vjeru. Sud u tim slučajevima nije dužan prihvatiti iskaz bilo kojeg od vještaka, ali ne može ni samostalno utvrditi spornu činjenicu jer se radi o činjenicama za koje zakon nalaže obvezno vještačenje. Tada, kao i u svim drugim slučajevima kada neka činjenica ostane nedokazana, ne preostaje drugo nego primijeniti pravilo in dubio pro reo (čl. 3 .

12 Schneider, K., Die Beurteilung der Zurechnungsfähigkeit, Stuttgart, Thieme, 1961. 
st. 2. Zakona o kaznenom postupku), tj. utvrditi činjenicu na način koji je povoljniji za okrivljenika. ${ }^{13}$ Iako se na pitanje što je za okrivljenika povoljnije ne može unaprijed odgovoriti, obično će za njega biti povoljnije da ga se proglasi neubrojivim. ${ }^{14}$

\subsection{Mogućnost shvaćanja značenja svojeg postupanja}

Mogućnost počinitelja da shvati značenje svojeg postupanja, koja se katkad naziva i intelektualnom sastavnicom ubrojivosti, često se dovodi u vezu sa sviješću o protupravnosti, iz čega slijedi shvaćanje da se počinitelj koji nije u mogućnosti shvatiti značenje svojeg postupanja nalazi u zabludi o protupravnosti. ${ }^{15}$ Međutim, sljedeći primjer iz psihijatrijske literature pokazuje da je to shvaćanje pogrešno. Počinitelj koji je bolovao od paranoidne shizofrenije počeo je sumnjati da ga žena truje, jer ga je poslužila čašicom rakije koja je imala čudan okus i od koje se počeo čudno osjećati. Također je počeo osjećati neobične mirise te je zaključio da ga žena truje nevidljivim plinom. Nakon liječenja, počinitelj se nakratko oporavio, ali je uskoro prestao uzimati lijekove pa su se simptomi vratili. Ponovno je počeo „osjećati“ da ga žena truje, pa se naposljetku odselio od kuće, no „trovanje“ se nastavilo, s time da su se u to tobože uključila i njegova djeca i punica. Zaključio je da cijela ženina obitelj truje svoje muževe kako bi se domogla njihove imovine. Uskoro se sa svojim sumnjama javio i policiji, koja ga je uputila da se obrati psihijatru, što je počinitelja navelo na misao da je i liječnik uključen u zavjeru. Uskoro je odlučio prekinuti ženinu ,zločinačku aktivnost“ pa ju je pokušao zadaviti dok je glačala u svojem stanu. Naposljetku je počinitelj optužen za pokušaj ubojstva i proglašen neubrojivim. ${ }^{16} \mathrm{U}$ navedenom je primjeru gotovo nemoguće iskonstruirati zabludu o protupravnosti, jer počinitelj zna da je ubojstvo zabranjeno, ali zbog svoje bolesti pogrešno percipira stvarnost pa pogrešno zaključuje da je napadnut.

Slična situacija pojavila se u predmetu VSRH, I Kž-87/97, u kojem je počinitelj koji boluje od paranoidne shizofrenije, želeći „spasiti hrvatski narod“, pošao u župni ured i ondje prisilio domaćicu ureda da s njime pođe u crkvu, gdje ju je, smatrajući da je u njoj sotona, izudarao nogama i metalnim raspelom, te je potom gazio dok nije preminula. Počinitelj ovdje pogrešno percipira stvarnost, tj. ne vara se samo o svojem pravu da nešto čini, već i o tome što zapravo čini; na kraju krajeva, kada bi domaćica doista bila sotona koju hitno treba ubiti kako bi se spasio cijeli jedan narod, protupravnost počiniteljeve radnje doista bi bila isključena.

Iz navedenih primjera slijedi da mogućnost shvaćanja značenja vlastitog postupanja treba lučiti od svijesti o protupravnosti, tj. da nemogućnost tog shvaćanja treba lučiti od zablude o protupravnosti. Takvo shvaćanje nije teško teorijski opravdati jer mogućnost shvaćanja nije isto što i samo shvaćanje, već nešto što mu prethodi,

13 Grozdanić, V., Škorić, M., Martinović, I., op. cit., str. 134-135.

14 Grozdanić, V., Škorić, M., Martinović, I., op. cit., str. 135.

15 Tako npr. Novoselec, P., op. cit., str. 213-214; Roxin, C., op. cit., str. 900.

16 Slučaj preuzet iz: Kozarić-Kovačić, D., Grubišić-Ilić, M., Grozdanić, V., Forenzička psihijatrija, Zagreb, Medicinska naklada, 2005., str. 149-150. Oznaka presude se ne navodi. Primjer korišten i u: Martinović, I., Institut namjere u kaznenopravnoj teoriji i sudskoj praksi, Rijeka, Pravni fakultet Sveučilišta u Rijeci, 2014., str. 277-278. 
odnosno predstavlja njegov preduvjet. ${ }^{17}$ Istina je da izostanak mogućnosti shvaćanja značenja vlastitog postupanja u konačnici sprečava počinitelja i da ostvari svijest o protupravnosti, no izostanak te svijesti kod neubrojivog počinitelja može biti i puka posljedica pogrešne percepcije o tome što čini, a ne nužno rezultat nedostatka znanja da se svojom radnjom (koju pravilno percipira) sukobljava s pravnom normom. U prilog tezi da intelektualna sastavnica ubrojivosti nije tek poseban slučaj svijesti o protupravnosti govori i zakonski tretman zablude o protupravnosti u kojoj se nalazi počinitelj čije su mogućnosti shvaćanja značenja svojeg postupanja smanjene, ali ne bitno (v. dolje, 4.). Općenito je pogrešno izostanak intelektualne sastavnice neubrojivosti povezivati sa zabludom o protupravnosti, ali jednako tako i sa zabludom o biću djela, zabludom o okolnostima koje isključuju protupravnost ili zabludom o okolnostima krajnje nužde koja isključuje krivnju. I izostanak mogućnosti shvaćanja značenja vlastitog postupanja mogao bi se, doduše, u kolokvijalnom smislu riječi podvesti pod pojam zablude, ali bi to onda bila zabluda sui generis koja isključuje krivnju.

Za razliku od odnosa ubrojivosti i svijesti o protupravnosti, odnos ubrojivosti i namjere nije teorijski niti praktično sporan. I neubrojiva osoba može postupati s namjerom, što uviđaju i sudovi. Kod takve osobe „postoji psihički proces donošenja odluke da poduzme određenu radnju (protupravno djelo), ali takva volja nije, kao kod zdrave osobe, proizašla iz slobodnog misaonog procesa u kojem bi se ta osoba, u dvojbi između postupanja u skladu s pravnom normom i protupravnog ponašanja, opredijelila za nepravo. Volja ubrojivog počinitelja kaznenog djela (odluka da ga počini) rezultat je njegovog slobodnog opredjeljenja jer kod njega ne postoje teže duševne smetnje koje bi utjecale na njegovu sposobnost da u određenom slučaju ispravno postupi i koje bi time isključile njegovu sposobnost za krivnju i kaznenu odgovornost. Suprotno tome, volja, odnosno odluka neubrojive osobe da poduzme protupravnu radnju posljedica je njenih duševnih smetnji zbog kojih ona nije mogla ispravno rasuđivati niti slobodno odlučivati (...). Dakle, i kod neubrojive osobe postoji namjera usmjerena na počinjenje protupravne radnje, ali ona je determinirana njenim duševnim smetnjama“ (VSRH, I Kž-361/16). Da neubrojivost ne isključuje namjeru pokazuje i već spomenuti primjer u kojem je počinitelj pokušao ubiti ženu koja ga „truje“. I taj je počinitelj, očigledno, posjedovao nekakav oblik svijesti i išao za time da ubije svoju ženu ili je barem pristao na to. Rješenja koja bi u tom slučaju negirala namjeru ne samo da bi bila protivna zdravorazumskom pravnom osjećaju o tome što je namjera, nego bi rezultirala i neprihvatljivim sistemskim posljedicama.

$\mathrm{U}$ prethodnom je odlomku navedeno da u teoriji i praksi nije sporno da neubrojivi počinitelj može postupati s namjerom te da intelektualna sastavnica namjere nije isto što i intelektualna sastavnica ubrojivosti, ali nije odgovoreno na pitanje koja je sadržajna razlika između tih dviju intelektualnih sastavnica. Autorima koji intelektualnu sastavnicu ubrojivosti izjednačuju sa sviješću o protupravnosti na to je pitanje naizgled lako odgovoriti, jer je za njih - kako je već napomenuto - ta razlika identična onoj između namjere i svijesti o protupravnosti. To je rješenje naizgled vrlo

17 Slično i Rudolphi, H.,-J., Unrechtstsbewusstsein, Verbotsirrtum und Vermeidbarkeit des Verbotsirrtums, Göttingen, Schwartz, 1969., str. 201. 
elegantno jer se njime izbjegava upadanje u dogmatske neprilike, no ono nije životno jer paranoidni počinitelji često pogrešno „testiraju realnost“" ali pritom mogu zadržati svijest o tome što je dopušteno, a što zabranjeno.

Posegne li se za teorijskim spoznajama o intelektualnoj komponenti namjere, razlikovanje intelektualne sastavnice namjere i ubrojivosti bit će mnogo jasnije. U njemačkoj se teoriji navodi da svijest (znanje) kao element namjere postoji kad ,pojedincu informacija aktualno stoji na raspolaganju, kada ne mora poduzeti nikakve daljnje korake da bi dobio informaciju niti mora aktivirati svoje memorijske kapacitete." ${ }^{18}$ Navedeni kriterij uvelike doprinosi razlikovanju intelektualne sastavnice namjere i ubrojivosti, tj. objašnjava kako je moguće da neubrojiva osoba postupa s namjerom. U primjeru paranoidnog počinitelja koji je pokušao ubiti svoju ženu, njemu su sve relevantne informacije aktualno stajale na raspolaganju i nije trebao poduzeti nikakve daljnje korake da se dodatno informira. Za ocjenu da je počinitelju informacija ,aktualno stajala na raspolaganju“, dovoljno je da je on raspolagao znanjem na temelju kojeg bi se od adresata norme (prosječnog čovjeka) moglo očekivati da ne poduzme spornu radnju. U prethodnom primjeru, počinitelj je nesporno raspolagao znanjem na temelju kojeg bi se od prosječnog čovjeka moglo očekivati da ne pokuša zadaviti svoju ženu. ${ }^{19}$

\subsection{Mogućnost vladanja svojom voljom}

Zakon propisuje da neubrojivost postoji kada počinitelj nije mogao shvatiti značenje svojeg postupanja ili nije mogao vladati svojom voljom (alternativni uvjet). Time se daje do znanja da je, osim počinitelja koji nema ni intelektualnu ni voljnu sastavnicu ubrojivosti, neubrojiv i počinitelj koji ne može shvatiti značenje svojeg postupanja, ali može vladati svojom voljom, kao i počinitelj koji može shvatiti značenje svojeg postupanja, ali ne može vladati svojom voljom. I potonji slučajevi postoje u sudskoj praksi, npr. kada je sud ustvrdio da je irelevantno to što se vještaci ne slažu je li počiniteljica bila svjesna značenja svojeg djela ako je nesporno da ona nije mogla vladati svojom voljom (VSRH, I Kž-214/00). Slučajevi u kojima je uvid u značenje svojeg postupanja očuvan, ali je voljna sastavnica ubrojivosti isključena ili smanjena mogući su osobito u slučajevima intoksikacije jer se smatra da se mogućnost shvaćanja značenja postupanja počinje gubiti u kasnijoj fazi negoli mogućnost vladanja svojom voljom. Mogućnost vladanja svojom voljom ne treba izjednačavati s mogućnošću racionalnog ponašanja. ${ }^{20}$

Teorijski položaj mogućnosti vladanja svojom voljom kao preduvjeta ubrojivosti u pravno-dogmatskom smislu manje je sporan negoli intelektualna sastavnica ubrojivosti, jer u ovom segmentu ne dolazi do (potencijalnog ili stvarnog) preklapanja s drugim institutima poput namjere ili svijesti o protupravnosti. Istina je, doduše, da

18 Cit. prema: Roxin, C., op. cit., str. 499.

19 Opširnije o potrebnoj razini svijesti kod namjere uz osvrt na problem svijesti neubrojivih počinitelja v. Martinović, I., op. cit., str. 275-284.

20 Perron, W., Weißer, B., u: Schönke/Schröder, Strafgesetzbuch, München, Beck, 2014., § 20, rubni broj 29. 
i namjera i ubrojivost imaju voljnu sastavnicu, ali je razlika između njih očita: kod namjere je relevantna volja počinitelja, a kod ubrojivosti mogućnost vladanja njome.

Premda u strogo dogmatskom smislu voljna sastavnica ubrojivosti nije problematična, u doktrini su se pojavili sporovi oko pitanja odnosa ove sastavnice ubrojivosti i filozofskog problema slobode volje. Ovisno o stavu prema slobodi volje, formirali su se gnostički i agnostički tabor. Prvi je tvrdio da je nesloboda volje neubrojive osobe empirijski dokaziva, a drugi da je to pitanje nedokazivo i da ga stoga ne treba ni postavljati. ${ }^{21} \mathrm{U}$ svakom slučaju, kazneno pravo može i mora funkcionirati $\mathrm{i}$ bez da se na to pitanje dade definitivan odgovor. To pokazuje i novija doktrina koja, izbjegavajući da se izrijekom izjasni o „vječnom problemu slobode volje“, bit krivnje vidi u protupravnom ponašanju unatoč „normativnoj podražljivosti“ počinitelja. Iz takvih viđenja krivnje slijedi da je voljna sastavnica neubrojivosti isključena kada počinitelj niti uz aktivaciju svih svojih mogućnosti nije u stanju prilagoditi svoje ponašanje normama. ${ }^{22}$

\section{BITNO SMANJENA UBROJIVOST}

Između dva pola, potpune ubrojivosti i neubrojivosti, nalazi se smanjena ubrojivost kao prijelazno stanje. Smanjeno ubrojivi počinitelji podskupina su ubrojivih počinitelja čija je krivnja smanjena zbog toga što imaju reducirane mogućnosti shvaćanja značenja svojeg postupanja ili vladanja svojom voljom, zbog čega je i njihova krivnja umanjena. Smanjena ubrojivost može biti rezultat svih četiriju „biopsiholoških“ osnova, a u praksi je češća od neubrojivosti. Kao i neubrojivost, i smanjena ubrojivost utvrđuje se in concreto, u trenutku počinjenja djela i s obzirom na konkretnu radnju koju je počinitelj poduzeo, a ne in abstracto.

Zakon poznaje dva stupnja smanjene ubrojivosti. Lakši stupanj, tj. „nebitno“ smanjena ubrojivost olakotna je okolnost. KZ u odredbi koja uređuje odmjeravanje kazne (čl. 47.) smanjenu ubrojivost ne navodi izrijekom kao olakotnu okolnost, ali to, s obzirom na to da smanjena ubrojivost podrazumijeva i smanjenu krivnju, nedvojbeno slijedi iz čl. 47. st. 2., koji propisuje da visina kazne ne smije prekoračiti stupanj krivnje. ${ }^{23}$ Ipak, „,nebitno“ smanjena ubrojivost nije okolnost koja bi dopuštala „probijanje“ donje granice zakonom propisane kazne. Za razliku od „nebitno“ smanjene ubrojivosti, bitno smanjena ubrojivost temeljem čl. 26. KZ-a fakultativna je osnova za ublažavanje kazne.

Propisivanje različitih kaznenopravnih učinaka „nebitno“ i bitno smanjene ubrojivosti nameće potrebu za razlikovanjem tih dviju dogmatskih kategorija. Kao i pri utvrđivanju neubrojivosti, i ovdje su za odluku relevantni i nalaz i mišljenje vještaka i normativna ocjena suca. Ne slaže li se sudac s nalazom ili mišljenjem vještaka o stupnju ubrojivosti (bilo u ocjeni radi li se o bitno ili „nebitno“ smanjenoj ubrojivosti, ili o tome je li ubrojivost smanjena ili je okrivljenik u potpunosti ubrojiv),

21 Za kratak pregled vidi Streng, F., u: Münchenner Kommentar zum StGB, München, Beck, 2017., § 20, rubni broj 53-54.

22 Perron, W., Weißer, B., op. cit., rubni broj 29.

23 Tako i Roxin, C., op. cit., str. 904, u kontekstu njemačkog prava. 
može odrediti obnovu vještačenja (čl. 317. i 218. Zakona o kaznenom postupku), a ostane li to pitanje i dalje nerazjašnjeno, dužan je primijeniti princip in dubio pro reo.

Do bitno smanjene ubrojivosti može doći zbog bitno smanjene mogućnosti shvaćanja značenja svojeg ponašanja ili zbog bitno smanjene mogućnosti vladanja svojom voljom. Iz okolnosti da je ublažavanje kazne moguće kad su počiniteljeve mogućnosti shvaćanja bitno smanjene, ali ne i kad su nebitno smanjene, proizlazi argument protiv već kritizirane teze da je intelektualna sastavnica ubrojivosti tek jedan oblik svijesti o protupravnosti (v. gore, 3. 2.). Kada bi ta teza bila istinita, „običan“ počinitelj koji se nalazi u otklonjivoj zabludi o protupravnosti bio bi bolje zakonski tretiran od počinitelja s duševnim smetnjama koji se nalazi u istoj zabludi. Naime, dok se „običnom“ počinitelju valorizira svaka otklonjiva zabluda (tako da mu se može ublažiti kazna), počinitelju koji je u zabludi o protupravnosti zbog teže duševne smetnje vrednovala bi se samo zabluda o protupravnosti koja je rezultat bitno smanjene mogućnosti shvaćanja značenja svojeg ponašanja. Drugim riječima, zbog otklonjive zablude o protupravnosti koja je rezultat teže duševne smetnje ne bi se mogla ublažiti kazna počinitelju koji je „nebitno“ smanjeno ubrojiv. Jedan način da se zaobiđe ova dogmatska nedosljednost bio bi prihvatiti ideju da bitno smanjeno ubrojiv počinitelj nije svjestan protupravnosti, iako je to uz više napora mogao biti, dok je ,nebitno“ smanjeno ubrojiv počinitelj ipak svjestan protupravnosti. Međutim, takva bi pravna konstrukcija bila veoma udaljena od životnog iskustva. Prihvati li se, pak, koncepcija prema kojoj intelektualna sastavnica ubrojivosti nije tek specijalan slučaj svijesti o protupravnosti, nego posebna dogmatska kategorija, takvih problema neće biti.

\section{SAMOSKRIVLJENA NEUBROJIVOST}

U slučajevima kada se počinitelj svojom krivnjom doveo u stanje neubrojivosti, neopravdano bi bilo isključiti njegovu krivnju, iako se dok čini djelo nalazi u stanju u kojem ne može shvatiti značenje svojeg postupanja ili vladati svojom voljom. Stoga KZ u čl. 25. propisuje da se ne smatra neubrojivim počinitelj koji se uporabom alkohola, droga ili na drugi način svojom krivnjom doveo u stanje u kojem nije mogao shvatiti značenje svojeg postupanja ili nije mogao vladati svojom voljom, ako je u vrijeme kad se dovodio u takvo stanje kazneno djelo što ga je počinio bilo obuhvaćeno njegovom namjerom ili je glede toga kaznenog djela kod njega postojao nehaj, a zakon propisuje kažnjivost i za taj oblik krivnje. U teoriji se ta figura naziva actio libera in causa (,,radnja slobodna u uzroku"). U slučajevima samoskrivljene neubrojivosti gleda se prethodna krivnja počinitelja, tj. njegov odnos prema djelu u trenutku kada se dovodio u stanje neubrojivosti, npr. u trenutku kada se dovodio u stanje opijenosti.

S obzirom na to da je u kaznenom pravu za ocjenu ubrojivosti, kao i drugih subjektivnih elemenata kaznenog djela, relevantno vrijeme počinjenja djela, postavlja se pitanje teorijskog opravdanja instituta samoskrivljene neubrojivosti. Radi li se ovdje o iznimci od načela da se ubrojivost ocjenjuje u trenutku počinjenja djela ili, pak, vremenom počinjenja djela treba smatrati trenutak u kojem se počinitelj dovodio 
u stanje neubrojivosti? To je pitanje važno i iz praktičnih razloga pa mu vrijedi posvetiti pozornost.

Koncepcija prema kojoj samoskrivljena neubrojivost nije iznimka od načela da se ubrojivost ocjenjuje u trenutku počinjenja djela (tzv. model bića djela, Tatbestandsmodell) polazi od toga da je vrijeme počinjenja djela u slučaju samoskrivljene neubrojivosti vrijeme kada se počinitelj dovodio $u$ takvo stanje. To mišljenje prihvaća većina njemačke literature. ${ }^{24}$ Prema drugoj koncepciji (tzv. model iznimke, Ausnahmemodell), kod samoskrivljene neubrojivosti trenutak počinjenja djela nije trenutak kada se počinitelj dovodio u stanje u kojem nije imao mogućnost shvatiti značenje svojeg postupanja ili vladati svojom voljom, nego trenutak u kojem je bivajući samoskrivljeno neubrojiv poduzimao spornu radnju. ${ }^{25}$

U njemačkoj literaturi „modelu bića djela“ prigovara se da neosnovano izjednačava namjerno pokretanje kauzalnog lanca s prouzročenjem posljedice, jer npr. opijanje s ciljem silovanja nije isto što i samo silovanje. ${ }^{26} \mathrm{U}$ obranu tog modela ističe se, pak, da počinitelj ne mora biti ubrojiv za cijelo vrijeme počinjenja djela da bi ga se smatralo ubrojivim. Bitno je da u trenutku započinjanja pokušaja počinitelj bude ubrojiv, a hoće li biti ubrojiv i kasnije tijekom počinjenja nije odlučno, osim ako dođe do bitnog odstupanja kauzalnog toka. Pobornici modela bića djela povlače, dakle, paralelu između slučajeva samoskrivljene neubrojivosti i slučajeva u kojima neubrojivost nastupa iz drugih razloga, tvrdeći da je u oba slučaja dovoljno da je počinitelj bio ubrojiv u trenutku započinjanja pokušaja. Na daljnji prigovor da se opijanje i dalje ne može smatrati trenutkom počinjenja djela jer ono ne predstavlja započinjanje pokušaja, zagovornici povlače paralelu s posrednim počiniteljstvom. No, iako počinjenje djela u stanju samoskrivljene neubrojivosti ima mnogo toga zajedničkoga s posrednim počiniteljstvom, jer počinitelj koji skrivi svoje stanje neubrojivosti u određenom smislu koristi samoga sebe kao „sredstvo“, analogija ipak nije potpuna. Posredno je počiniteljstvo, primjerice, isključeno kod vlastoručnih kaznenih djela, a negiranje mogućnosti actio libera in causa kod takvih djela nema nikakva kriminalnopolitičkog smisla. Nema razloga da netko tko uzme drogu kako bi se doveo u stanje da može počiniti rodoskvrnuće ne odgovara jednako kao i ubrojivi počinitelj koji takvo što učini. Tatbestandsmodell u takvom primjeru očito zakazuje. Uostalom, posredni počinitelj (u pravilu) gubi vlast nad radnjom neposrednog počinitelja u trenutku započinjanja pokušaja, pa je nakon toga za njega nemoguć dobrovoljni odustanak. Stoga bi nas analogija posrednog počiniteljstva i actio libera in causa dovela do apsurdnog zaključka da se počinitelja koji se sam doveo u stanje neubrojivosti ne može osloboditi od kazne ako dobrovoljno odustane od počinjenja djela. $^{27}$

24 V. npr. Roxin, C., op. cit., str. 914-920.

25 Tu koncepciju zagovara osobito Hruschka, J., npr. u radu „Der Begriff der actio libera in causa und die Begründung ihrer Strafrbarkeit“, Juristische Schulung, 1968., str. 554, kao i u kasnijim radovima.

26 Ibid., str. 556.

$27 \mathrm{Na}$ to upozorava Neumann, U., Zurechnung und „Vorverschulden“: Vorstudien zu einem dialogischen Modell strafrechtlicher Zurechnung, Berlin, Duncker \& Humblot, 1985., str. 39. 
U Njemačkoj je prihvaćanje modela bića djela uvjetovano ponajprije činjenicom da tamošnji zakon ne poznaje pojam samoskrivljene neubrojivosti. S obzirom na to, kaznena odgovornost za actio libera in causa deducira se iz odredbe koja regulira neubrojivost (§ $20 \mathrm{StGB}$ ), tako što se riječi „pri počinjenju djela“ (bei der Begehung der Tat) tumače u skladu s modelom bića djela, tj. tako što se trenutkom počinjenja djela smatra trenutak samoskrivljenog dovođenja u stanje neubrojivosti i zaključuje da počinitelj u trenutku počinjenja nije bio neubrojiv. Za razliku od modela bića djela, model iznimke ondje nema zakonsko uporište, već ga je potrebno eruirati iz običajnog prava, a takvo što je vrlo suspektno zbog načela zakonitosti.. ${ }^{28} \mathrm{U}$ postojećem su hrvatskom zakonodavstvu takvi manevri nepotrebni jer je samoskrivljena neubrojivost izrijekom uređena. Čini se, štoviše, da je izričaju Kaznenog zakona bliži model iznimke, jer iako zakon ne navodi izrijekom koji se trenutak ima smatrati vremenom počinjenja djela, znakovito je da govori o vremenu u kojem se počinitelj „dovodio u takvo stanje“, diferencirajući time, barem neizravno, to vrijeme od vremena počinjenja djela.

Prihvaćanje modela iznimke kao bližeg zakonskoj ekspresiji, ali i logici sustava kaznenog djela, rezultira mogućnošću razdvajanja trenutka u kojem se počinitelj dovodio u stanje opijenosti od trenutka u kojem započinje pokušaj kaznenog djela. Prema modelu bića djela, pokušaj mora otpočeti najkasnije dok je počinitelj još uvijek ubrojiv; u suprotnom krivnja za djelo počinjeno u stanju nemogućnosti shvaćanja tj. vladanja ne postoji. Međutim, model iznimke omogućuje da se za počinjenje djela u stanju samoskrivljene neubrojivosti kazni i počinitelj koji je u trenutku samoskrivljenog dovođenja u stanje neubrojivosti bio u stadiju pripremnih radnji. Tko ubrojiv nabavi otrov odlučivši njime ubiti žrtvu (pripremna radnja), ali ga tek nakon što se dovede u stanje samoskrivljene neubrojivosti naspe žrtvi u piće, prema modelu bića djela mogao bi odgovarati za ubojstvo jedino ako bi se uzelo da je pokušaj ubojstva već bio započeo u trenutku dok je počinitelj još bio ubrojiv. Prihvaćanje modela iznimke omogućuje, pak, da se takvi slučajevi bez neprimjerenog „rastezanja“ instituta pokušaja podvedu pod ubojstvo, a što očito odgovara i intenciji zakonodavca izraženoj u čl. 25.

Prihvaćanje modela iznimke važno je i za pitanje mora li se počinitelj s namjerom dovesti u stanje neubrojivosti da bi odgovarao za namjerno počinjenje djela ili je dovoljno da se njegova namjera proteže samo na djelo koje je počinio, dok je s obzirom na sam čin dovođenja u stanje samoskrivljene neubrojivosti dovoljan i nehaj. Model bića djela traži dvostruku namjeru (Doppelvorsatz), koja mora obuhvatiti i počinjeno djelo i dovođenje u stanje neubrojivosti. Do takvog se zaključka dolazi analogijom s posrednim počiniteljstvom, ${ }^{29} \mathrm{kod}$ kojeg se traži da počinitelj ima namjeru i u pogledu radnje neposrednog počinitelja, i u pogledu svoje vlastite radnje. Model iznimke takvo što ne zahtijeva; da bi se počinitelj osudio za namjeru, dovoljno je da je djelo počinjeno s namjerom, a počinitelj se u stanje samoskrivljene neubrojivosti može dovesti i iz nehaja, npr. kada se počinitelj koji je odlučio ubiti ženu prije samog zločina iz dosade ili navike opije i dovede u stanje samoskrivljene neubrojivosti. I u

28 Tako i njemački Savezni vrhovni sud u odluci BGHSt 42, 235.

29 Roxin, C., op. cit., str. 920. 
tom je pogledu model iznimke bliži izričaju KZ-a, koji, doduše, govori o namjernom i nehajnom počinjenju djela, ali ne ulazi u pitanje je li za dovođenje u stanje neubrojivosti potrebna namjera ili nehaj. Uostalom, i sam atribut „samoskrivljena“ $\mathrm{u}$ nazivu instituta upućuje na to da je oblik krivnje s kojim se okrivljenik dovodi u neubrojivo stanje irelevantan za opstojnost samoskrivljene neubrojivosti.

Model iznimke prikladniji je napokon i za teorijsko utemeljenje samoskrivljene smanjene ubrojivosti. Model bića djela, koji samoskrivljeno neubrojivog počinitelja tretira kao sredstvo u svojim vlastitim rukama, ne može negirati da se takva neobična misaona figura ne može primijeniti na samoskrivljeno smanjeno ubrojive, koji zadržavaju određen stupanj ubrojivosti, pa na tom planu usporedba s posrednim počiniteljstvom prestaje vrijediti.

Sukladno navedenom, sve teorijske postavke modela iznimke prihvatljive su s aspekta aktualnoga hrvatskog kaznenog zakonodavstva, ali i opće strukture pojma kaznenog djela, koju u slučaju prihvaćanja tog modela ne treba suspektno „rastezati“ da bi se u nju uklopila kaznena odgovornost za actio libera in causa. Tu se pokazuje prednost izričite zakonske regulacije samoskrivljene neubrojivosti, kakva postoji u Hrvatskoj i Švicarskoj ${ }^{30}$ (od koje je Hrvatska, tj. Jugoslavija najvjerojatnije i preuzela ovu odredbu u Krivičnom zakoniku iz 1951.), u usporedbi sa stanjem u Njemačkoj i drugim državama koje ovu materiju nisu izrijekom zakonski uredile.

\section{NEUBROJIVOST I SIGURNOSNE MJERE DE LEGE LATA I DE LEGE FERENDA}

U hrvatskoj je doktrini pitanje mogućnosti izricanja kaznenopravnih sankcija neubrojivim počiniteljima izazivalo, a mjestimice i danas izaziva, bitne dvojbe. Bez podrobnijeg ulaženja u genezu i kronologiju spora, ${ }^{31}$ autor će se osvrnuti na bit dileme, a to je mogućnost primjene sigurnosnih mjera prema neubrojivim počiniteljima.

Devedesetih se godina među dijelom teoretičara oblikovala misao da tretman neubrojivih počinitelja (ako su opasni) treba regulirati usporedno s tretmanom ostalih osoba s duševnim smetnjama. U to je vrijeme zakonski okvir prisilne hospitalizacije bio izrazito manjkav, pa je pokrenuta inicijativa za donošenje Zakona o zaštiti osoba s duševnim smetnjama koji bi usporedo regulirao hospitalizaciju neubrojivih osoba i nedelinkvenata. U tom kontekstu, Grozdanić je isticala da je „pitanje neuračunljivih delinkvenata samo (...) dio sveobuhvatnog propisa o zaštiti duševnog zdravlja i zaštiti osoba s duševnim smetnjama, kojim se nastojala pomiriti suprotnost između potrebe za zaštitom tih osoba i potrebe za zaštitom društva od njih. Dakle, duševno bolesni delinkventi i nedelinkventi svedeni su na isti nazivnik, jer ono što je uvjet za prisilnu hospitalizaciju i puštanje - opasnost i prestanak opasnosti - ne može se razlikovati u duševno abnormalne osobe koja jest i koja nije počinila kazneno djelo." ${ }^{\text {"32 Naglasila }}$ je i da „kaznenopravni sustav nije predviđen ni pripremljen za bavljenje medicinskim

30 Da je švicarskom pravu bliži Ausnahmemodell tvrdi i Roxin, C., op. cit., str. 915.

31 O tome više v. Škorić, M. i Srdoč, E., op. cit., str. 939-943.

32 Grozdanić, V., Pravni položaj osoba s duševnim smetnjama u Hrvatskoj, Hrvatski ljetopis za kazneno pravo i praksu, vol. 3., br. 2., 1996., str. 506. 
problemima“..$^{33}$

Stajalište da neubrojivima nije mjesto u kaznenom pravu doživjelo je svoju kulminaciju u načelu krivnje koje je sadržavao KZ iz 1997. Sukladno tom zakonu, prema osobama koje nisu krive nisu se mogle primjenjivati nikakve kaznenopravne sankcije, pa niti sigurnosne mjere. Time je doseg načela krivnje bitno proširen u odnosu na uvriježenu maksimu nulla poena sine culpa (nema kazne bez krivnje). Krivnja je pretvorena u temelj svih kaznenopravnih sankcija, zbog čega su kritičari tvrdili da su sve one „na taj način bile izjednačene s kaznom." ${ }^{34}$ Zagovornici navedenog rješenja smatrali su da bi primjena sigurnosnih mjera prema neubrojivim osobama bila ,dezavuiranje načela krivnje, odnosno zanemarivanje činjenice da je kazneno pravo okrenuto prema krivim i odgovornim počiniteljima djela i da kao takvo nije pripremljeno da se bavi pitanjima koja po svojem sadržaju pripadaju medicini (liječenje). ${ }^{\text {(35 }}$

Intencija zakonodavca da iz kaznenoga zakonodavstva izmjesti prisilnu hospitalizaciju neubrojivih osoba rezultirala je time da se prema njima nisu više mogle primjenjivati nikakve sigurnosne mjere, pa niti npr. zabrana upravljanja motornim vozilom. Štoviše, nijedna od tih mjera nije se više mogla primjenjivati niti prema počiniteljima čija je krivnja bila isključena iz drugih razloga, a ne zbog neubrojivosti, primjerice, prema počiniteljima koji su postupali u neotklonjivoj zabludi o protupravnosti. Navedeno se rješenje s aspekta proklamiranog dualizma kaznenopravnih sankcija teško može teorijski opravdati. ${ }^{36} \mathrm{U}$ njemačkom pravnom krugu, iz kojega je i preuzeta ideja o „dvotračnosti“ kaznenopravnih sankcija, misao o različitom temelju i svrsi kazni i sigurnosnih mjera nije sporna. Na samom početku svojega kapitalnog udžbenika, tu ideju pregnantno izražava Roxin, tvrdeći da „svaka kazna podrazumijeva krivnju počinitelja pri počinjenju djela koje se dogodilo u prošlosti, a svaka sigurnosna mjera, naprotiv, kontinuiranu opasnost počinitelja u budućnosti (...). Nedostaje li krivnja, npr. zbog duševnih smetnji (...) ili zbog neotklonjive zablude o protupravnosti (...), kažnjavanje počinitelja je isključeno. Međutim, u slučaju nedostajuće krivnje itekako se mogu izreći sigurnosne mjere, pod uvjetom da je počinitelj zbog svojeg stanja opasan za zajednicu“..37

33 Ibid., str. 507.

34 Novoselec, P., op. cit., str. 196. Slično i Đurđević, Z., Pravni položaj počinitelja kaznenih djela s duševnim smetnjama, Zagreb, Hrvatsko udruženje za kaznene znanosti i praksu, 2002., str. 237.

35 Grozdanić, V., u: Kozarić-Kovačić, D., Grubišić-Ilić, M., Grozdanić, V., op. cit., str. 30.

36 Tripalo i Burić tvrde da „u predmetima protiv neubrojivih osoba (...) nije uočena (...) potreba izricanja tim optuženicima sigurnosnih mjera koje bi odgovarale onima čije izricanje neubrojivim osobama sada uvodi KZ/11.“ V. Tripalo, D. i Burić, Z., Položaj neubrojivih počinitelja protupravnih djela u kontekstu novog hrvatskog kaznenog zakonodavstva, Hrvatski ljetopis za kazneno pravo i praksu, vol. 19., br. 2., 2012., str. 509. Taj argument nije uvjerljiv jer bi to značilo da kod neubrojivih osoba a priori ne postoji opasnost koja bi opravdavala zabranu upravljanja motornim vozilom i druge sigurnosne mjere. Protuargument bi mogao biti da se neubrojivim osobama može zabraniti upravljanje motornim vozilom na temelju izvanrednog nadzornog zdravstvenog pregleda (čl. 232.-234. Zakona o sigurnosti prometa na cestama), no to bi bilo tek rješenje iz nužde kojim bi se bezrazložno izigravao sustav sigurnosnih mjera kao sankcija koje se izriču opasnom, a ne nužno i krivom počinitelju.

37 Roxin, C., op. cit., str. 2. Više o tim pitanjima v. Martinović, I., Pledoaje za brisanje zakonske 
Aktualni KZ vratio se klasičnom načelu krivnje, koje krivnju čini pretpostavkom kazne, ali ne i drugih kaznenopravnih sankcija. Time je reafirmirana ideja o različitom smislu kazni i sigurnosnih mjera. Druga, teorijski jednako dosljedna mogućnost bila je prihvatiti monistički sustav sankcija, tj. izmjestiti sigurnosne mjere iz kaznenog prava i omogućiti njihovo izricanje u sklopu neke druge grana prava i u nekom drugom obliku sudskog postupka. Međutim, hrvatski zakonodavac nije se odlučio za tako radikalno rješenje nego je ostao pri već tradicionalnom dualizmu sankcija.

S obzirom na odustanak zakonodavca od „proširenog“ načela krivnje iz KZ/97, postavlja se pitanje sudbine drugog noviteta koji je uveden tim zakonom, a to je primjena prema neubrojivim osobama mjera prisilnog smještaja i liječenja na slobodi propisanih Zakonom o zaštiti osoba s duševnim smetnjama, umjesto primjene sigurnosne mjere obveznog psihijatrijskog liječenja, koju je predviđalo ranije hrvatsko kazneno zakonodavstvo. Bez obzira na vremensku koincidenciju uvođenja tih dvaju noviteta, treba naglasiti da povratak klasičnom načelu krivnje ni na koji način ne ugrožava koncepciju sukladno kojoj se prema neubrojivima ne primjenjuje sigurnosna mjera obveznog psihijatrijskog liječenja predviđena KZ-om. Klasično načelo krivnje s navedenom koncepcijom nije ni u kakvoj koliziji pa od nje nema razloga odustajati, osobito jer se u Zakonu o zaštiti osoba s duševnim smetnjama mjere prisilnog smještaja i liječenja na slobodi opsežnije reguliraju, dok bi u KZ-u toj materiji moglo biti posvećeno tek nekoliko odredaba.

Postojećem se zakonskom rješenju ipak može uputiti jedna zamjerka. Riječ je o tome da se sigurnosna mjera obveznog psihijatrijskog liječenja, koja se više ne može primjenjivati prema neubrojivima, još uvijek može primjenjivati prema smanjeno ubrojivim počiniteljima. Takvo rješenje nije logično jer ako je zakonodavac zaključio da je primjenu prisilnih psihijatrijskih mjera, iz ovog ili onog razloga, nužno urediti u posebnom zakonu, izvan KZ-a, tada to isto treba vrijediti i za bitno smanjeno ubrojive počinitelje. ${ }^{38}$ Nomotehnička intervencija u tom smjeru bila bi relativno jednostavna. Kada bi istom odlukom bila izrečena kazna zatvora i prisilni smještaj, vrijedio bi ponajprije čl. 4. Zakona o zaštiti osoba s duševnim smetnjama, koji propisuje da se njegove odredbe na odgovarajući način primjenjuju i na osobe s duševnim smetnjama koje se nalaze na izdržavanju kazne zatvora. Uz manje zakonske izmjene, sigurnosna mjera obveznog psihijatrijskog liječenja mogla bi se, dakle, ukinuti bez štetnih posljedica.

odredbe o sastojcima krivnje, Hrvatski ljetopis za kazneno pravo i praksu, vol. 21., br. 1., 2014., str. 3-22.

38 Takvo rješenje, barem posredno, zagovaraju Grozdanić, V. i Kurtović, A., Smanjena ubrojivost prema novom zakonskom uređenju, Hrvatski ljetopis za kazneno pravo i praksu, vol. 6., br. 2., 1999., str. 529. 


\section{LITERATURA}

1. Bačić, F., Kazneno pravo - opći dio, Zagreb, Informator, 1998.

2. Beulke, W., Strafprozessrecht, Heidelberg, Müller, 2010.

3. Đurđević, Z., Pravni položaj počinitelja kaznenih djela s duševnim smetnjama, Zagreb, Hrvatsko udruženje za kaznene znanosti i praksu, 2002.

4. Frank, S., Teorija kaznenog prava, Zagreb, Školska knjiga, 1955.

5. Grozdanić, V., Pravni položaj osoba s duševnim smetnjama u Hrvatskoj, Hrvatski ljetopis za kazneno pravo i praksu, vol. 3., br. 2., 1996.

6. Grozdanić, V. i Kurtović, A., Smanjena ubrojivost prema novom zakonskom uređenju, Hrvatski ljetopis za kazneno pravo i praksu, vol. 6., br. 2., 1999.

7. Grozdanić, V., Škorić, M., Martinović, I., Kazneno pravo - opći dio, Rijeka, Pravni fakultet Sveučilišta u Rijeci, 2013.

8. Hruschka, J., Der Begriff der actio libera in causa und die Begründung ihrer Strafrbarkeit, Juristische Schulung, 1968.

9. Kozarić-Kovačić, D., Grubišić-Ilić, M., Grozdanić, V., Forenzička psihijatrija, Zagreb, Medicinska naklada, 2005.

10. Martinović, I., Institut namjere u kaznenopravnoj teoriji i sudskoj praksi, Rijeka, Pravni fakultet Sveučilišta u Rijeci, 2014.

11. Martinović, I., Pledoaje za brisanje zakonske odredbe o sastojcima krivnje, Hrvatski ljetopis za kazneno pravo i praksu, vol. 21., br. 1., 2014.

12. Münchenner Kommentar zum StGB, München, Beck, 2017.

13. Neumann, U., Zurechnung und „Vorverschulden“: Vorstudien zu einem dialogischen Modell strafrechtlicher Zurechnung, Berlin, Duncker \& Humblot, 1985.

14. Novoselec, P., Opći dio kaznenog prava, Osijek, Pravni fakultet Osijek, 2016.

15. Roxin, C., Strafrecht - Allgemeiner Teil, sv. 1, München, Beck, 2006.

16. Rudolphi, H.,-J., Unrechtstsbewusstsein, Verbotsirrtum und Vermeidbarkeit des Verbotsirrtums, Göttingen, Schwartz, 1969.

17. Schneider, K., Die Beurteilung der Zurechnungsfähigkeit, Stuttgart, Thieme, 1961.

18. Schönke/Schröder, Strafgesetzbuch, München, Beck, 2014.

19. Srzentić, N., Stajić, A., Lazarević, Lj., Krivično pravo SFRJ - opšti deo, Beograd, Savremena administracija, 1978.

20. Škorić, M. i Srdoč, E., Pravni položaj neubrojivih počinitelja protupravnih djela u Republici Hrvatskoj, Zbornik radova Pravnog fakulteta u Splitu, vol. 52., br. 4., 2015.

21. Tripalo, D. i Burić, Z., Položaj neubrojivih počinitelja protupravnih djela u kontekstu novog hrvatskog kaznenog zakonodavstva, Hrvatski ljetopis za kazneno pravo i praksu, vol. 19., br. 2., 2012. 


\section{Igor Martinović*}

Summary

\section{THE CONCEPT OF MENTAL CAPACITY IN CRIMINAL JURISPRUDENCE, LEGISLATION AND CASE LAW}

Mental capacity is legally defined as an element of culpability. The Criminal Code describes mental incapacity (Article 24), voluntary intoxication (Article 25) and substantially diminished mental capacity (Article 26). This paper firstly deals with the notion of mental incapacity, especially its "biopsychological" and "normative" component. The relationship between judge and psychiatrist in determining mental capacity is also discussed. After this, the concepts of substantially diminished mental capacity and voluntary intoxication are analysed. The final chapter discusses the possibility of imposing security measures on mentally incapable persons. Throughout the paper, judicial decisions related to the mentioned concepts are analysed.

Keywords: mental capacity, mental incapacity, diminished mental capacity, voluntary intoxication, criminal law.

\section{Zussamenfassung}

\section{BEGRIFF DER SCHULDFÄHIGKEIT IN DER THEORIE, GESETZGEBUNG UND PRAXIS DES STRAFRECHTES}

Im Strafgesetzbuch wird Schuldfähigkeit als eines der Schuldelemente bestimmt. Das Gesetz definiert diesen Begriff nicht, aber es definiert den Begriff der Schuldunfähigkeit (Art. 24), der selbstverschuldeten Schuldunfähigkeit (Art. 25.) und der wesentlich verminderten Schuldfähigkeit (Art. 26.). Zuerst wird in der Arbeit der Begriff der Schuldunfähigkeit bearbeitet, insbesondere seine „biopsychologische“ und „normative“ Komponente. Die Beziehung zwischen dem Richter und dem Psychiater bei der Feststellung der Schuldfähigkeit wird auch besprochen. Nachfolgend werden die Begriffe der wesentlich verminderten Schuldfähigkeit und der selbstverschuldeten Schuldunfähigkeit analysiert, wobei das so genannte Ausnahmemodell und das Tatbestandsmodell in Betracht gezogen werden. Abschließend wird hinsichtlich schuldunfähiger Personen über die Möglichkeit der Anordnung von Maßregeln der Sicherung de lege lata und de lege ferenda diskutiert. Die auf genannte gesetzgebende und theoretische Rechtsinstitute bezogenen Rechtsprechungen werden durch die ganze Arbeit hindurch analysiert.

* Igor Martinović, Ph. D., Assistant Professor, Faculty of Law, University of Rijeka; imartinovic@ pravri.hr. 
Schlüsselwörter: Schuldfähigkeit, Schuldunfähigkeit, verminderte

Schuldunfähigkeit, selbstverschuldete Schuldunfähigkeit, Strafrecht.

Riassunto

\section{LA NOZIONE DI CAPACITÀ DI INTENDERE E VOLERE NELLA TEORIA GIUSPENALISTICA, NELLA LEGISLAZIONE E NELLA GIURISPRUDENZA}

La legge penale annovera la capacità di intendere e volere tra gli elementi della colpa valutabili ai fini dell'imputabilità, senza in realtà definirne la nozione. Definisce, per converso, lo stato di incapacità (art. 24), lo stato preordinato di incapacità di intendere e volere (art. 25) e la ridotta capacità (art. 26). In primo luogo nello scritto si esamina la nozione di incapacità di intendere e volere, in ispecie le sue componenti „biopsicologica“ e „normativa“. Si dibatte altresì del rapporto tra il giudice e lo psichiatra in occasione dell'accertamento della capacità di intendere e volere. In seguito si analizzano la ridotta capacità e lo stato preordinato di incapacità, valutando all'uopo il c.d. modello dell'eccezione e dell'evento del reato. Nella parte conclusiva dello scritto si discute della possibilità di emanare misure cautelari a soggetti incapaci de lege lata e de lege ferenda. Nell'intero scritto si procede all'analisi critica della giurisprudenza relativa agli istituti giuridici trattati.

Parole chiave: capacità di intendere e volere, incapacità di intendere e volere, ridotta capacità, stato preordinato di incapacità di intendere e volere, diritto penale. 